\title{
Optimasi Kinerja Instalasi Pengolahan Air Limbah Industri Penyamakan Kulit Magetan
}

\author{
Nastiti Sri Fatmawati, Joni Hermana, dan Agus Slamet \\ Teknik Lingkungan, Fakultas Teknik Sipil dan Perencanaan, Institut Teknologi Sepuluh Nopember \\ (ITS) \\ Jl. Arief Rahman Hakim, Surabaya 60111 Indonesia

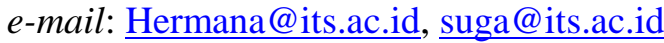

\begin{abstract}
Abstrak - Industri Penyamakan Kulit Magetan terdapat 78 unit pengusaha penyamakan kulit. Produk kulit finish yang dihasilkan sebanyak \pm 8.2006 .180.440 $\mathrm{feet} / \mathrm{tahun}$ dan limbah cair yang dihasilkan hingga mencapai $1500 \mathrm{~m}^{3} / \mathrm{hari}$. Industri Penyamakan Kulit Magetan telah dilengkapi dengan sarana IPAL dengan kapasitas $600 \mathrm{~m}^{3} / \mathrm{hari}$. Hasil dari pemeriksaan parameter belum terpenuhinya baku mutu air limbah sesuai dengan PERGUB JATIM No. 72 Tahun 2013. Optimasi ini menggunakan metode evaluasi dan perhitungan optimasi. Evaluasi pertama yaitu menghitung efisiensi pengolahan dan proses pengolahan kemudian dari hasil evaluasi maka perlu melakukan perhitungan optimasi dari aspek teknis dan aspek biaya. Hasil evaluasi pengolahan biologis diperoleh nilai parameter sangat rendah, setelah di optimasi dengan merencanakan \% efisiensi pengolahan dan penambahan debit air limbah didapatkan nilai MLSS pada bak aerasi 1 sebesar 1223 mg/l, bak aerasi 2 sebesar $774 \mathrm{mg} / \mathrm{l}$, solid flux lumpur aktif 1 sebesar $1,17 \mathrm{~kg} / \mathrm{m}^{2}$.hari, solid flux lumpur aktif 2 sebesar 0,6 $\mathrm{kg} / \mathrm{m}^{2}$.hari, F/M rasio lumpur aktif 1 sebesar $0,08 \mathrm{~kg}$ BOD $/ \mathrm{kg}$ MLSS, F/M rasio lumpur aktif 2 sebesar $0,1 \mathrm{~kg}$ BOD/kg MLSS, waktu detensi lumpur aktif 1 sebesar 2,5 jam, waktu detensi lumpur aktif 2 sebesar 2,8 jam, kebutuhan udara lumpur aktif 1 sebesar 121,5 $\mathrm{m}^{3} /$ hari, dan kebutuhan oksigen lumpur aktif 2 sebesar $105 \mathrm{~m}^{3} / \mathrm{hari}$. Hasil perhitungan optimasi biaya pemeliharaan menghabiskan dana sebesar Rp. 9.617.700,- per bulan.
\end{abstract}

Kata Kunci - Efisiensi, Evaluasi, Lumpur Aktif, Optimasi.

\section{PENDAHULUAN}

I NDUSTRI penyamakan kulit merupakan industri yang mengolah kulit mentah menjadi kulit jadi yang proses pengerjaannya menggunakan air dengan kapasitas besar [1]. Sedangkan proses penyamakan kulit merupakan proses pengawetan kulit binatang menggunakan bahan kimia, limbah cair yang ditimbulkan merupakan limbah cair yang mengandung logam berat krom $(\mathrm{Cr})$, krom trivalen $\left(\mathrm{Cr}^{3+}\right)$ dan krom heksavalen $\left(\mathrm{Cr}^{6+}\right)$, sehingga usaha ini akan menghasilkan limbah cair yang mengandung berbagai polutan organik dari bahan baku dan polutan kimia dari bahan pembantu proses [2]. Di samping itu juga dihasilkan limbah padat dari hasil pembersihan daging, bulu, dan gumpalan lemak. Limbah padat juga banyak mengandung kapur, garam, dan bahan kimia pembantu dalam proses penyamakan [3]

Industri Penyamakan Kulit Magetan terdapat 78 unit pengusaha penyamakan kulit. Produk kulit finish yang dihasilkan sebanyak kurang lebih 8.2006.180.440 feet/tahun, dengan menyerap tenaga kerja \pm 550 orang. Untuk menghindari terjadinya pencemaran lingkungan akibat limbah ini, maka Industri Penyamakan Kulit Magetan telah dilengkapi dengan sarana IPAL dengan kapasitas $600 \mathrm{~m}^{3} / \mathrm{hari}$.

Secara operasional IPAL di Industri Penyamakan Kulit Magetan belum efektif untuk meningkatkan air limbah yang dihasilkan. Ketidakefektifan ini disebabkan proses yang terjadi di pengolahan biologis yang tidak dapat berjalan dengan baik, sehingga mempengaruhi kinerja IPAL dan membuat efluen limbah cair yang dibuang ke badan air mengandung logam berat, bau yang menyengat, dan membuat warna air di badan air menjadi keruh karena terdapat kandungan amonia yang tinggi sehingga mengganggu masyarakat sekitar [4] ,sehingga dibutuhkan solusi untuk mengoptimasi pengolahan biologis IPAL yang dapat digunakan sesuai kapasitas dan lahan yang tersedia tetapi memperhitungkan efluen standart sesuai parameter baku mutu [5].

Oleh karena itu diperlukan Optimasi Kinerja pengolahan biologis Instalasi Pengolahan Air Limbah untuk Industri Penyamakan Kulit yang sesuai dengan kebutuhan Industri Penyamakan Kulit yang dihasilkan dari IPAL.

\section{METODE PERENCANAAN}

\section{A. Pengumpulan Data}

Kegiatan pengumpulan data dibagi menjadi 3 jenis yaitu data primer, data sekunder, dan hasil sampling. Data sekunder yang diperlukan terdiri dari data influen yang masuk, data eksisting lahan, diagram alir instalasi pengolahan limbah penyamakan kulit, dokumen hasil pemeriksaan berkala limbah penyamakan kulit untuk mengetahui kualitas effluen IPAL. Data primer yang digunakan yaitu data debit influen, eksisting IPAL, debit effluen, dan debit resirkulasi, operasi pengolahan limbah penyamakan kulit. Data hasil sampling yaitu data primer dari hasil analisis di laboratorium terhadap sampel yang dianalisis dengan baku mutu [5 $\left.5^{\mathrm{b}}\right]$

\section{B. Pengolahan Data}

Pada Evaluasi dan Optimasi kali ini akan melakukan optimasi dari Instalasi Pengolahan Air Limbah (IPAL) 
penyamakan kulit. Penjelasan mengenai tahap-tahap evaluasi dan optimasi sebagai berikut:

1) Tahap Evaluasi

Ide evaluasi berasal dari kondisi eksisting yang tidak sesuai dengan kondisi ideal. Kondisi eksisting yang melatarbelakangi evaluasi ini adalah tidak optimalnya pengolahan biologis pada IPAL Industri Penyamakan Kulit Magetan.

2) Tahap Optimasi

Pada tahap perencanaan ini menggunakan evaluasi dari unit yang telah ada. Tahapan kegiatan evaluasi dan optimasi secara garis besar adalah sebagai berikut:

a. Studi literatur

b. Pengumpulan data

c. Analisa efisiensi pengolahan biologis IPAL Industri Penyamakan Kulit Magetan

d. Evaluasi premiliminary design

e. Evaluasi pengolahan biologis pada IPAL Industri Penyamakan Kulit Magetan

f. Evaluasi pengolahan biologis dengan perbandingan baku mutu

g. Perhitungan optimasi kinerja pada aspek teknis dan aspek finansial pengolahan biologis IPAL Industri Penyamakan Kulit Magetan

h. Kesimpulan dan saran

\section{GAMBARAN UMUM}

Industri Penyamakan Kulit Magetan mempunyai IPAL dengan kapasitas $600 \mathrm{~m}^{3} /$ hari yang terdiri atas tanah seluas $2.450 \mathrm{~m}^{2}$. Effluen yang diolah berasal dari 78 unit penyamak kulit penghasil limbah cair yang terdiri dari proses soaking, liming, deliming, bating, spliting, pickling, tanning, retanning, dan air cucian proses.

Proses pengolahan air limbah di IPAL Industri Penyamakan Kulit Kabupaten Magetan merupakan proses pengolah secara lengkap meliputi:

1) Proses Secara Fisik

IPAL Industri Penyamakan Kulit Magetan mempunya unitunit yang memproses secara fisik air limbah yang masuk, yaitu pada bar screen, bak ekualisasi, bak pengendap, bak filtrasi, dan bak reuse. Untuk pengolahan lumpur secara fisik di kumpulkan terlebih dahulu di bak pengumpul lumpur, dan untuk pengeringan lumpur masuk kedalam Sludge Drying Bed.

2) Proses Secara Kimiawi

Air limbah yang masuk di IPAL Industri Penyamakan Kulit Magetan diolah secara kimiawi pada bak netralisasi, pada bak netralisasi ditambahkan bahan kimia yaitu asam sulfat, tawas, dan flokulan.

3) Proses Secara Biologis (lumpur aktif)

Proses secara biologis pada IPAL Industri Penyamakan Kulit Magetan diolah secara biologis dengan sistem lumpur aktif pada bak aerasi. Ada 3 bak aerasi dan 3 bak pengendap II pada IPAL Industri Penyamakan Kulit Magetan. Sistem aerasi yang digunakan yaitu sistem
Difuser Aerator dengan bantuan penggunaan blower. Untuk layout IPAL dapat dilihat pada Gambar 1.

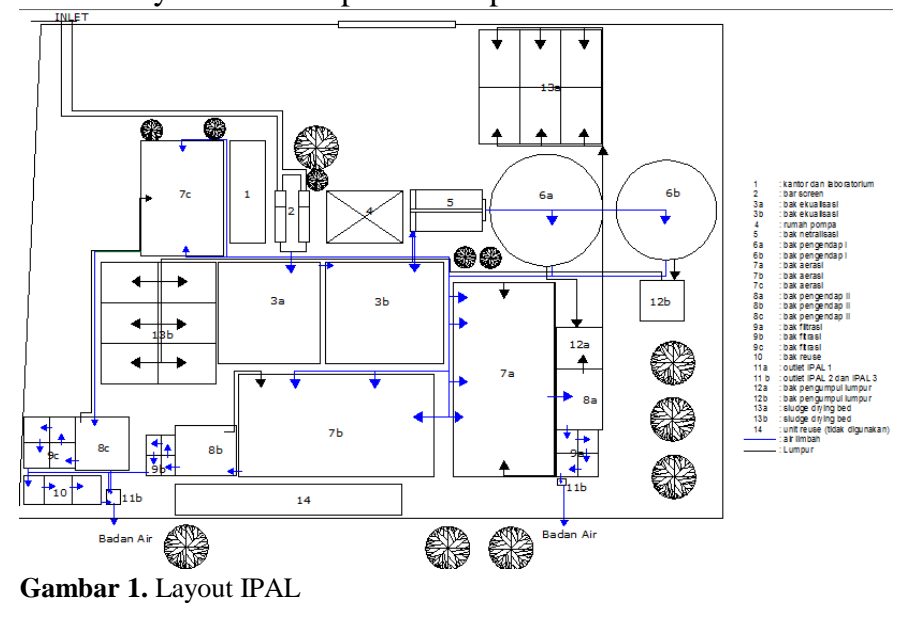

\section{PEMBAHASAN}

Analisa pembahasan dilakukan berdasarkan hasil survey lapangan dan kajian literatur. Unit yang ditinjau adalah bak aerasi dan bak pengendap II. Dari hasil analisa ini diharapkan dapat mengoptimasi kinerja dari pengolahan biologis pada IPAL Industri Penyamakan Kulit Magetan.

\section{A. Evaluasi Parameter}

Dalam evaluasi ini yang diukur adalah suhu, $\mathrm{pH}, \mathrm{BOD}_{5}$, COD, TSS. Prinsip evaluasi kinerja adalah melakukan pemeriksaan dan menjaga konsentrasi oksigen terlarut dalam air limbah yang terdapat pada tangki aerasi 1 , aerasi 2, dan aerasi 3 , serta pengaturan jumlah lumpur yang diresirkulasi.

1) Suhu

Hasil pemeriksaan terhadap air limbah Industri Penyamakan Kulit Magetan diketahui rata-rata suhunya yaitu $30^{\circ} \mathrm{C}$, sehingga masih memenuhi syarat untuk mokroorganisme untuk berkembang biak dan melakukan proses pengolahan air limbah.

2) $\mathrm{pH}$

hasil pengukuran $\mathrm{pH}$ pada masing-masing unit pengolahan air limbah Industri Penyamakan Kulit Magetan yaitu pada rentang $\mathrm{pH} 7,0$ sampai 8,0. Hasil pengukuran $\mathrm{pH}$ masih masuk kedalam baku mutu yaitu $6,0-9,0 .\left[5^{\mathrm{c}}\right]$

3) $\mathrm{BOD}_{5}$

Dari hasil pemeriksaan yang telah dilakukan, nilai $\mathrm{BOD}_{5}$ pada air limbah industri penyamakan kulit Magetan yang terdapat pada influen tangki aerasi 1 yaitu $119,4 \mathrm{mg} / \mathrm{l}$, tangki aerasi 2 yaitu $114,2 \mathrm{mg} / \mathrm{l}$, dan tangki aerasi 3 yaitu $116,7 \mathrm{mg} / \mathrm{l}$. Sedangkan pada effluen bak pengendap II $1=$ $108,5 \mathrm{mg} / \mathrm{L}$, effluen bak pengendap II $2=106,1 \mathrm{mg} / \mathrm{L}$, dan effluen bak pengendap II $3=99,1 \mathrm{mg} / \mathrm{L}$ dengan efisiensi penurunan sebesar $41,16 \%$ dimana parameter $\mathrm{BOD}_{5}$ pada masing-masing unit aerasi belum memenuhi baku mutu sebesar $50 \mathrm{mg} / \mathrm{L}\left[5^{\mathrm{d}}\right]$ serta kriteria desain efisiensi penurunan sebesar $75-90 \%$. [9 $\left.{ }^{a}\right]$

4) $\mathrm{COD}$

Dari hasil pemeriksaan yang telah dilakukan, nilai COD 
pada air limbah industri penyamakan kulit Magetan yang terdapat pada influen tangki aerasi 1 yaitu $279,1 \mathrm{mg} / \mathrm{l}$, tangki aerasi 2 yaitu $272,7 \mathrm{mg} / \mathrm{l}$, dan tangki aerasi 3 yaitu $279,1 \mathrm{mg} / \mathrm{l}$. Sedangkan pada effluen bapk pengendap II $1=$ $220,9 \mathrm{mg} / \mathrm{L}$, effluen bak pengendap II $2=206,8 \mathrm{mg} / \mathrm{L}$, dan effluen bak pengendap II $3=178,2 \mathrm{mg} / \mathrm{L}$ dimana parameter COD pada masing-masing unit aerasi belum memenuhi baku mutu yaitu kadar maksimum sebesar $110 \mathrm{mg} / \mathrm{L}$. [5 $]$

5) TSS

Hasil pemeriksaan yang telah dilakukan, nilai TSS effluen pada bak pengendap II $1=82 \mathrm{mg} / \mathrm{l}$, bak pengendap II $2=78$ $\mathrm{mg} / \mathrm{l}$, dan bak pengendap II $3=72 \mathrm{mg} / \mathrm{l}$. Sedangkan nilai TSS influen pada tangki aerasi 1 yaitu $105 \mathrm{mg} / \mathrm{l}$, tangki aerasi 2 yaitu $102 \mathrm{mg} / \mathrm{l}$, dan tangki aerasi 3 yaitu $103 \mathrm{mg} / \mathrm{l}$.

\section{B. Evaluasi Efisiensi Removal}

Dari hasil analisa TSS, BOD, dan COD tersebut maka dapat diketahui nilai efisiensi removal dari lumpur aktif. Nilai persentase removal kadar pencemar ditentukan sebagai berikut

- Lumpur Aktif 1

$$
\begin{aligned}
\% \text { BOD removal } & =\frac{\text { BODin }- \text { BODout }}{\text { BODin }} \times 100 \% \\
& =\frac{119,4-108,5}{119,4} \times 100 \% \\
& =9,12 \% \\
\% \text { TSS removal } & =\frac{\text { TSSin-TSSout }}{\text { TSSin }} \times 100 \% \\
& =\frac{105-82}{105} \times 100 \% \\
& =21,90 \% \\
\% \text { COD removal } & =\frac{\text { CODin }- \text { CODout }}{\text { CODin }} \times 100 \% \\
& =\frac{279,1-220,9}{279,1} \times 100 \% \\
& =20,85 \%
\end{aligned}
$$

Dengan cara yang sama untuk menentukan efisiensi removal BOD,COD,dan TSS pada lumpur aktif 2, dan lumpur aktif 3 yaitu:

- Lumpur Aktif 2

$\%$ BOD removal $=7,09 \%$

$\%$ TSS removal $=23,5 \%$

$\%$ COD removal $=24,1 \%$

$$
\begin{array}{ll}
\text { - Lumpur Aktif } 3 & \\
\% \text { TSS removal } & =30 \% \\
\% \text { BOD removal } & =15,08 \% \\
\% \text { COD removal } & =36,15 \%
\end{array}
$$

Dari hasil perhitungan \% removal tersebut menunjukkan kondisi yang belum optimum dari unit aerasi untuk menyisihkan zat organik. Dapat dilihat dari hasil removal yang tidak termasuk dalam kriteria desain yaitu 75-90\% removal.

\section{Evaluasi Dimensi}

Untuk mengetahui apakah bak aerasi bekerja secara optimal atau tidak perlu diketahui evaluasi dari dimensi bak aerasi. Berikut adalah perhitungan evaluasi pada dimensi bak aerasi.

- Bak Aerasi 1

Diketahui :

\begin{tabular}{|c|c|c|}
\hline $\begin{array}{l}\text { Panjang } \\
\text { Lebar }\end{array}$ & $\begin{array}{l}=19 \mathrm{~m} \\
=10 \mathrm{~m}\end{array}$ & $\begin{aligned} \text { Kedalaman } & =3,1 \mathrm{~m} \\
\text { Volume } & =589 \mathrm{~m}^{3}\end{aligned}$ \\
\hline
\end{tabular}

$$
\begin{array}{rlrl}
\Theta \mathrm{c} & =20 \text { hari } & \mathrm{S}=87,2 \mathrm{mg} / \mathrm{l} \\
\mathrm{Q} & =397,4 \mathrm{~m}^{3} / \mathrm{hari} & \mathrm{X}=1020 \mathrm{mg} / \mathrm{l} \\
\mathrm{Y} & =0,6 \mathrm{mg} / \mathrm{mg} & \mathrm{Kd}=0,06 \text { per hari } \\
\text { So } & =119,4 \mathrm{mg} / \mathrm{l} & & \\
\mathrm{V} & =\frac{\theta_{c} Q Y\left(S_{0}-S\right)}{X\left(1+K_{d} \theta_{C}\right)} & \\
& =\frac{20 \text { hari } \times 397 \mathrm{~m}^{3} / \text { hari } \times 0,6(119,4 \mathrm{mg} / \mathrm{l}-87,2 \mathrm{mg} / l)}{1020 \mathrm{mg} / l(1+0,06 / \text { harix } 20 \text { hari })}
\end{array}
$$

Rasio P:L $=2: 1 \quad \mathrm{~L}=3,31 \mathrm{~m}$

Htotal $=3,1 \mathrm{~m} \quad P=6,63 \mathrm{~m}$

$\mathrm{Lx} 2 \mathrm{~L}$ x $3,1 \mathrm{~m}=68,36 \mathrm{~m}^{3}$

Dimensi kondisi aktualnya yaitu:

$\begin{array}{llll}\text { Panjang } & =19 \mathrm{~m} & \text { Kedalaman } & =3,1 \mathrm{~m} \\ \text { Lebar } & =10 \mathrm{~m} & \text { Volume } & =589 \mathrm{~m}^{3}\end{array}$

- Bak Aerasi 2

Diketahui :

$$
\begin{aligned}
& \Theta \mathrm{c}=20 \text { hari }
\end{aligned}
$$

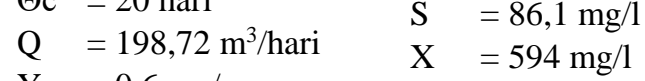

$$
\begin{aligned}
& \mathrm{Y}=0,6 \mathrm{mg} / \mathrm{mg} \quad \mathrm{Kd}=0,06 \text { per } \\
& \text { So }=114,2 \mathrm{mg} / \mathrm{l} \\
& \mathrm{V}=51,12 \mathrm{~m}^{3} \\
& \begin{array}{rlrl}
\text { Htotal } & =3,1 \mathrm{~m} & \mathrm{~L} & =2,8 \mathrm{~m} \\
\mathrm{Lx} 2 \mathrm{~L} \times 3,1 \mathrm{~m}=51,12 \mathrm{~m}^{3} & & P & =5,74 \mathrm{~m}
\end{array}
\end{aligned}
$$

Dimensi kondisi aktualnya yaitu:

- Bak Aerasi 3

Diketahui :

$$
\begin{array}{lll}
\Theta c & =20 \text { hari } & \mathrm{S}=84,9 \mathrm{mg} / \mathrm{l} \\
\mathrm{Q}=103,68 \mathrm{~m}^{3} / \text { hari } & \mathrm{X}=620 \mathrm{mg} / \mathrm{l} \\
\mathrm{Y}=0,6 \mathrm{mg} / \mathrm{mg} & \mathrm{Kd}=0,06 \text { per hari } \\
\text { So }=116,7 \mathrm{mg} / \mathrm{l} & & \\
\mathrm{V}=17,87 \mathrm{~m}^{3} & \mathrm{~L} \quad=1,78 \mathrm{~m} \\
\text { Htotal } \quad=2,8 \mathrm{~m} & \mathrm{P} \quad=3,57 \mathrm{~m} \\
\text { Lx 2L x 3,1m }=17,87 \mathrm{~m}^{3} & &
\end{array}
$$

Dimensi kondisi aktualnya vaitu:

$$
\begin{aligned}
& \text { Panjang }=11,3 \mathrm{~m} \quad \text { Kedalaman }=2,8 \mathrm{~m} \\
& \text { Lebar }=8 \mathrm{~m} \quad \text { Volume }=253,12 \mathrm{~m}^{3}
\end{aligned}
$$

Jadi perhitungan dimensi aktual dengan perhitungan berdasarkan parameter dari hasil laboratorium sangat berbeda, sehingga dapat disimpulkan bahwa pengolahan pada bak aerasi 1, bak aerasi 2, dan bak aerasi 3 tidak maksimal apabila menggunakan dimensi pada kondisi sebenarnya.

\section{Evaluasi Pengolahan Biologis}

\section{Evaluasi Lumpur Aktif 1}

\section{- F/M Rasio}

Berdasarkan perhitungan $\mathrm{F} / \mathrm{M}$ rasio sebesar $0,07 \mathrm{~kg}$ BOD/kg MLSS dengan kriteria desain 0,2-0,6 kg BOD $/ \mathrm{kg}$ MLSS [6 ${ }^{a}$ ] untuk kriteria desain,sehingga dapat disimpulkan bahwa kebutuhan mikroorganisme untuk mendegradasi kurang maksimal karena kekurangan asupan nutrisi, hasil perhitungan sebagai berikut. 
Volume bak lumpur aktif $1=589 \mathrm{~m}^{3}$

$$
\begin{aligned}
& \begin{array}{ll}
\text { Debit air limbah } & =397,4 \mathrm{~m}^{3} / \mathrm{hari} \\
\text { BOD5 inf rata-rata } & =119,4 \mathrm{mg} / \mathrm{l} \\
\text { BOD5 eff rata-rata } & =108,5 \mathrm{mg} / \mathrm{l} \\
\text { MLSS } & =1020 \mathrm{mg} / \mathrm{l}
\end{array} \\
& \begin{aligned}
& \mathrm{F} / \mathrm{M}=\frac{Q \times S_{0}}{V \times X} \\
&= \frac{397,4 \mathrm{~m}^{3} / \text { hari } \times 119,4 \mathrm{mg} / \mathrm{l}}{589 \mathrm{~m}^{3} \times 1020 \mathrm{mg} / \mathrm{l}} \\
&=0,07 \mathrm{~kg} \mathrm{BOD} / \mathrm{kg} \text { MLSS }(\mathrm{KD}: 0,05-0,2 \mathrm{~kg} \mathrm{BOD} / \mathrm{kg} \text { MLSS })
\end{aligned}
\end{aligned}
$$

\section{- SVI (Sludge Volume Index)}

SVI untuk lumpur aktif 1 belum memenuhi kriteria yaitu sebesar 355,88 ml/g dengan Kriteria Desain 100-150 ml/g [6 $6^{\mathrm{b}}$ ]. Sehingga pada lumpur aktif 1 terjadi bulking akibat pengendapan lumpur yang tidak baik karena melebihi nilai kriteria desain yang telah ditentukan. Perhitungan SVI pada lumpur aktif 1 sebagai berikut:

$$
\begin{aligned}
\text { SVI } & =\frac{1000 \times V_{S}}{M L S S} \\
& =\frac{1000 \times 363}{1020 \mathrm{mg} / \mathrm{l}} \\
& =355,88 \mathrm{ml} / \mathrm{g}(100-150 \mathrm{ml} / \mathrm{g}) \text { TIDAK OK! }
\end{aligned}
$$

\section{- Rasio Resirkulasi}

Rasio resirkulasi pada lumpur aktif 1 yaitu 0,24. dengan kriteria desain untuk tipe lumpur aktif yaitu berkisar 0,25-1 [7a]. Dari hasil perhitungan didapatkan bahwa rasio resirkulasi belum memenuhi kriteria desain.

$$
\begin{aligned}
\mathrm{r} & =\frac{Q_{r}}{Q} \\
& =\frac{97,2 m^{3} / \text { hari }}{397,4 m^{3} / \text { hari }} \\
& =0,24(\mathrm{KD}: 0,25-1) \text { TIDAK OK! }
\end{aligned}
$$

\section{- Umur Lumpur}

Kriteria desain dari umur lumpur yaitu selama 3-15 hari $\left[7^{\mathrm{b}}\right]$. Dari hasil perhitungan didapatkan umur lumpur 20 hari. Sehingga apabila umur lumpur > dari 15 hari menyebabkan partikel flok menjadi terlalu kecil dan fraksi kehidupan sel dalam biomassa menjadi rendah.untuk perhitungan umur lumpur sebagai berikut:

$$
\begin{aligned}
\Theta \mathrm{c} & =\frac{V \times X}{Q_{w} \times X_{r}} \\
& =\frac{397,4 \mathrm{~m}^{3} \times 1020 \mathrm{mg} / \mathrm{l}}{10,69 \mathrm{~m}^{3} / \text { hari } \times 2809,91 \mathrm{mg} / \mathrm{lMLSS}} \\
& =20 \text { hari (KD: } 3-15 \text { hari) TIDAK OK! }
\end{aligned}
$$

- Waktu Detensi(HRT) dan waktu proses/biodegradasi

Hasil perhitungan dinyatakan bahwa waktu detensi pada lumpur aktif 1 yaitu selama 1,48 hari. Dan waktu proses/biodegradasi $(\Theta \mathrm{H})$ selama 1,19 hari

$$
\begin{aligned}
& \Theta=\frac{V}{Q}=\frac{589 m^{3}}{397,4 m^{3} / \text { hari }}=1,48 \text { hari OK!(16-36 jam) }\left[7^{c}\right] \\
& \Theta \mathrm{H}=\frac{V}{Q \times Q_{r}}=\frac{589 m^{3}}{397,4 m^{3} / \text { hari }+97,2 m^{3} / \text { hari }}=1,19 \text { hari }
\end{aligned}
$$

- Volumetric Loading

Hasil perhitungan yang dilakukan diketahui bahwa debit air limbah penyamakan kulit yang masuk yaitu $397,4 \mathrm{~m}^{3} /$ hari dan BODin yaitu 119,4 mg/l, sehingga didapatkan nilai VL yaitu $0,08 \mathrm{~kg} / \mathrm{m}^{3}$.hari. perhitungan sebagai berikut:

$$
\begin{aligned}
\mathrm{VL}=\frac{Q \times S_{0}}{V} & =\frac{397,4 \mathrm{~m}^{3} / \text { hari } \times 119,4 \mathrm{mg} / l}{589 \mathrm{~m}^{3}}: 1000 \\
& =0,08 \mathrm{~kg} / \mathrm{m}^{3} \cdot \text { hari (KD:0,6-1,6) TIDAK OK! }
\end{aligned}
$$

- Kebutuhan Oksigen

Hasil perhitungan kebutuhan oksigen teoritis proses lumpur aktif pada IPAL Industri Penyamakan Kulit Magetan yaitu pada lumpur aktif 1 sebesar $142,17 \mathrm{~m}^{3} /$ hari. Apabila dibandingkan dengan kriteria desain yaitu 90-125 $\mathrm{m}^{3} /$ hari [8] sehingga disimpulkan bahwa kebutuhan oksigen pada lumpur aktif 1 melebihi kriteria desain. Untuk perhitungan kebutuhan udara sebagai berikut:

$$
\begin{aligned}
& \mathrm{Px}=\text { Yobs } \mathrm{Q}\left(\mathrm{S}_{0}-\mathrm{S}\right) / 1000 \\
& =\frac{0,27 \times 397,4 m^{3} \text { har }(119,4 m g / l-108,5 m g / l)}{(1000)} \\
& 1000 \\
& =1,16 \mathrm{~kg} / \mathrm{hari} \\
& \mathrm{Kg} \mathrm{O}_{2}=\frac{Q\left(S_{0}-S\right)}{B O D_{5} / B O D_{L}}-1,42 P_{x} \\
& =\frac{397,4 \mathrm{~m}^{3} / \text { hari }(119,4 \mathrm{mg} / \mathrm{l}-108,5 \mathrm{mg} / \mathrm{l})}{1000}-1,42 \times 3,48 \mathrm{~kg} / \mathrm{hari} \\
& =38,3 \mathrm{~kg} / \mathrm{hari} \\
& \mathrm{SOR}=\frac{N}{\left[\frac{C_{s w} \beta F_{a}-C}{C_{s w}}\right](1,024)^{T-20} 20} \\
& =\frac{38,3 \mathrm{~kg} / \text { hari }}{\left[\frac{9,15 \mathrm{mg} / \mathrm{l} \times 0,9 \times 0,99-1,5 \mathrm{mg} / \mathrm{l}}{9,15 \mathrm{mg} \cdot \mathrm{l}}\right](1,024)^{30} \times 20} \\
& =2,07 \mathrm{~kg} / \mathrm{hari}
\end{aligned}
$$

Kebutuhan udara teoritis diasumsikan bahwa udara mengandung $21 \% \mathrm{O}_{2}$, densitas udara $1,3 \mathrm{~kg} / \mathrm{m}^{3}$

$$
\text { Qudara }=\frac{S O R}{1,3 \mathrm{~kg} / \mathrm{m}^{3} \times 0,21}=\frac{2,07 \mathrm{~kg} / \mathrm{hari}}{1,3 \mathrm{~kg} / \mathrm{m}^{3} \times 0,21}=7,58 \mathrm{~m}^{3} / \mathrm{hari}
$$

Asumsi bahwa efisiensi difusi udara $8 \%$

$$
\text { Qudara teoritis }=\frac{Q_{\text {udara }}}{0,08}=\frac{7,58 \mathrm{~m}^{3} / \text { hari }}{0,08}=94,7 \mathrm{~m}^{3} / \text { hari }
$$

Direncanakan kebutuhan udara $150 \%$ kebutuhan udara teoritis, sehingga: 
Kebutuhan udara $=1,5 \times$ Qudara teoritis

$$
\begin{aligned}
& =1,5 \times 94,7 \mathrm{~m}^{3} / \text { hari } \\
& =142,17 \mathrm{~m}^{3} / \text { hari TIDAK OK! (KD:90- } 125 \\
& \mathrm{~m}^{3} / \text { hari) }
\end{aligned}
$$

Hasil evaluasi pada lumpur aktif 2 dan lumpur aktif 3 menggunakan perhitungan yang sama dengan lumpur aktif 1 , berikut tabel hasil evaluasi 3 lumpur aktif IPAL Industri Penyamakan Kulit.

- Konsentrasi mikroorganisme

Pada hasil analisa, nilai MLSS pada proses lumpur aktif sangat rendah, kondisi tersebut menyebabkan air limbah tidak dapat diolah secara maksimal, sehingga perlu adanya pembuktian melalui perhitungan MLSS secara matematis.

$$
\begin{aligned}
X & =\frac{Q Y\left(s_{0}-S\right)}{\theta\left(1+K_{d} \theta_{C}\right)} \\
& =\frac{397,4 m^{3} / \text { hari } \times 0,6(119,4 m g / l-108,5 m g / l)}{1,48 \text { har }(1+0,06 \times 20 \text { hari })} \\
& =798,21 \mathrm{mg} / 1 \text { TIDAK OK }(\text { KD: } 1500-4000)\left[7^{\mathrm{d}}\right]
\end{aligned}
$$

\begin{tabular}{|c|c|c|c|c|}
\hline Parameter & Unit & Nilai & $\begin{array}{l}\text { Kriteria } \\
\text { Desain }\end{array}$ & keterangan \\
\hline \multirow[t]{3}{*}{$\begin{array}{l}\text { MLSS } \\
(\mathrm{mg} / \mathrm{l})\end{array}$} & $\begin{array}{l}\text { Lumpur Aktif } \\
1\end{array}$ & 796,21 & $1500-4000$ & Tidak OK \\
\hline & $\begin{array}{l}\text { Lumpur Aktif } \\
2\end{array}$ & 150 & $1500-4000$ & Tidak OK \\
\hline & $\begin{array}{l}\text { Lumpur Aktif } \\
3\end{array}$ & 363,51 & $1500-4000$ & Tidak OK \\
\hline \multirow{3}{*}{$\begin{array}{l}\mathrm{SF} \\
\left(\mathrm{kg} / \mathrm{m}^{2} . \text { hari }\right.\end{array}$} & $\begin{array}{l}\text { Lumpur Aktif } \\
1\end{array}$ & 0,77 & $0,8-1$ & Tidak OK \\
\hline & $\begin{array}{l}\text { Lumpur Aktif } \\
2\end{array}$ & 0,2 & $0,8-1$ & Tidak OK \\
\hline & $\begin{array}{l}\text { Lumpur Aktif } \\
3\end{array}$ & 0,12 & $0,8-1$ & Tidak OK \\
\hline \multirow[t]{3}{*}{$\mathrm{F} / \mathrm{M}$} & $\begin{array}{l}\text { Lumpur Aktif } \\
1\end{array}$ & 0,07 & $0,05-0,2$ & $\mathrm{OK}$ \\
\hline & $\begin{array}{l}\text { Lumpur Aktif } \\
2\end{array}$ & 0,064 & $0,05-0,2$ & $\mathrm{OK}$ \\
\hline & $\begin{array}{l}\text { Lumpur Aktif } \\
3\end{array}$ & 0,077 & $0,05-0,2$ & $\mathrm{OK}$ \\
\hline \multirow[t]{3}{*}{$\mathrm{Td}$ (jam) } & $\begin{array}{l}\text { Lumpur Aktif } \\
1\end{array}$ & 3,24 & $1,5-2,5$ & TIDAK OK \\
\hline & $\begin{array}{l}\text { Lumpur Aktif } \\
2\end{array}$ & 6,5 & $1,5-2,5$ & TIDAK OK \\
\hline & $\begin{array}{l}\text { Lumpur Aktif } \\
3\end{array}$ & 12,2 & $1,5-2,5$ & TIDAK OK \\
\hline \multirow[t]{3}{*}{$\begin{array}{l}\text { Kebutuhan } \\
\text { Udara }\end{array}$} & $\begin{array}{l}\text { Lumpur Aktif } \\
1\end{array}$ & 9,61 & $190-125$ & TIDAK OK \\
\hline & $\begin{array}{l}\text { Lumpur Aktif } \\
2\end{array}$ & 3,64 & $1,5-2,5$ & TIDAK OK \\
\hline & $\begin{array}{l}\text { Lumpur Aktif } \\
3\end{array}$ & 3,93 & $1,5-2,5$ & TIDAK OK \\
\hline
\end{tabular}

Tabel 1.

Hasil Evaluasi Parameter Pengolahan Biologis

\section{E. Optimasi Pengolahan Biologis}

Pada hasil analisa, nilai MLSS pada proses lumpur aktif sangat rendah, kondisi tersebut menyebabkan air limbah tidak dapat diolah secara maksimal, sehingga perlu adanya optimasi jumlah biomass. Perhitungan optimasi sebagai berikut:

- Kondisi Eksisting

$$
\begin{aligned}
& \text { Volume bak lumpur aktif } 1=589 \mathrm{~m}^{3} \\
& \text { Debit air limbah } \quad=397,4 \mathrm{~m}^{3} / \mathrm{hari} \\
& \text { BOD5 inf rata-rata } \quad=119,4 \mathrm{mg} / \mathrm{l} \\
& \text { BOD5 eff BPII } \quad=108,5 \mathrm{mg} / \mathrm{l} \\
& \Theta \mathrm{c} \quad=20 \text { hari } \\
& \Theta \quad=1,48 \text { hari } \\
& \mathrm{X}=798,21 \mathrm{mg} / \mathrm{l} \\
& \mathrm{A}_{\text {aktual }}=27 \mathrm{~m}^{2} \\
& \mathrm{SF} \quad=\frac{Q X}{A}=\frac{397,4 \mathrm{~m}^{3} / \text { hari } \times 1,27 \mathrm{~kg} / \mathrm{m}^{3}}{27 \mathrm{~m}^{3}} \\
& =0,77 \mathrm{~kg} / \mathrm{m}^{2} \text {.jam TIDAK OK!(KD:0,8-1,0 } \\
& \left.\mathrm{kg} / \mathrm{m}^{2} . \mathrm{jam}\right)\left[9^{\mathrm{a}}\right] \\
& \text { OFR }=\frac{Q}{A}=\frac{397,4 m^{3} / \text { hari }}{27 m^{3}} \\
& =14,71 \mathrm{~m}^{3} / \mathrm{m}^{2} \text {.hari OK! (KD: } 15 \mathrm{~m}^{3} / \mathrm{m}^{2} \text {.hari) }\left[9^{\mathrm{b}}\right] \\
& \mathrm{Td}=\frac{V}{Q}=\frac{53,9 m^{3}}{397,4 m^{3} / \text { hari }} \\
& =3,24 \text { jam TIDAK OK!(KD: 1,5-2,5 jam) }\left[9^{c}\right]
\end{aligned}
$$

Dari hasil evaluasi proses pengolahan pada bak pengendap II didapatkan nilai OFR sebesar $14,71 \mathrm{~m}^{3} / \mathrm{m}^{2}$.hari memenuhi kriteria desain yaitu $15 \mathrm{~m}^{3} / \mathrm{m}^{2}$.hari $\left[9^{\mathrm{b}}\right]$ dengan waktu detensi yang cukup baik yaitu 3,24 jam, sehinggap pada evaluasi eksisting proses pengolahan bak pengendap II tidak terlalu menimbulkan masalah.

Optimasi menggunakan baku mutu sebagai pembanding

$$
\begin{aligned}
& \mathrm{V}=589 \mathrm{~m}^{3} \\
& \mathrm{Q} \quad=397,4 \mathrm{~m}^{3} / \text { hari } \\
& \mathrm{BOD}_{\text {in }}=119,4 \mathrm{mg} / \mathrm{l} \\
& \mathrm{BOD}_{\text {eff }}=50 \mathrm{mg} / 1\left[5^{\mathrm{f}}\right] \\
& \text { MLSS }_{\text {return }}=1200 \mathrm{mg} / \mathrm{l} \\
& \text { Qlumpur } \quad=97,2 \mathrm{~m}^{3} / \text { hari } \\
& \text { Umur lumpur }=20 \text { hari } \\
& \text { Td }=1,48 \text { hari } \\
& \mathrm{X}=\frac{397,4 \mathrm{~m}^{3} / \text { hari } \times 0,6(119,4 \mathrm{mg} / \mathrm{l}-50 \mathrm{mg} / \mathrm{l})}{1,48 \text { harl }(1+0,06 \times 20 \text { hari })} \\
& =5082 \mathrm{mg} / \mathrm{l}=6,35 \mathrm{~kg} / \mathrm{m}^{3}
\end{aligned}
$$

Direncanakan untuk debit air limbah yang masuk kedalam bak aerasi 1 yaitu sebesar $500 \mathrm{~m}^{3} /$ hari.

$$
\begin{aligned}
& \left.\Theta=\frac{V}{Q}=\frac{589 \mathrm{~m}^{3}}{500 \mathrm{~m}^{3} / \text { hari }}=1,48 \text { hari OK!(16-36 jam }\right)\left[7^{c}\right] \\
& X=\frac{500 \mathrm{~m}^{3} / \text { hari } \times 0,6(119,4 \mathrm{mg} / \mathrm{l}-50 \mathrm{mg} / \mathrm{l})}{1,17 \text { har }(1+0,06 \times 20 \text { hari })}=1223 \mathrm{mg} / \mathrm{l}
\end{aligned}
$$

Hasil perbandingan baku mutu dapat dilihat pada tabel 2 sebagai berikut

Tabel 2.

Perbandingan Baku Mutu Proses Pengolahan Biologis

\begin{tabular}{lllll}
\hline \hline $\begin{array}{l}\text { Paramet } \\
\text { er }\end{array}$ & Unit & Nilai & $\begin{array}{l}\text { Kriteria } \\
\text { Desain }\end{array}$ & keterangan \\
\hline $\begin{array}{l}\text { MLSS } \\
(\mathrm{mg} / \mathrm{l})\end{array}$ & Lumpur Aktif 1 & 5082 & $1500-4000$ & Tidak OK \\
& Lumpur Aktif 2 & 1177 & $1500-4000$ & Tidak OK \\
\hline \hline
\end{tabular}




\begin{tabular}{lllll}
\hline \hline & Lumpur Aktif 3 & 772 & $1500-4000$ & Tidak OK \\
$\begin{array}{l}\mathrm{SF} \\
\left(\mathrm{kg} / \mathrm{m}^{2} . \mathrm{h}\right. \\
\mathrm{ari})\end{array}$ & Lumpur Aktif 1 & 3,8 & $0,8-1$ & Tidak OK \\
& & & & \\
& & & & \\
& Lumpur Aktif 2 & 0,4 & $0,8-1$ & Tidak OK \\
$\mathrm{F} / \mathrm{M}$ & Lumpur Aktif 3 & 0,2 & $0,8-1$ & Tidak OK \\
& Lumpur Aktif 1 & 0,015 & $0,05-0,2$ & TIDAK OK \\
& Lumpur Aktif 2 & 0,03 & $0,05-0,2$ & TIDAK OK \\
\multirow{2}{*}{ Td (jam) $)$} & Lumpur Aktif 3 & 0,06 & $0,05-0,2$ & OK \\
& Lumpur Aktif 1 & 3,24 & $1,5-2,5$ & TIDAK OK \\
& Lumpur Aktif 2 & 6,5 & $1,5-2,5$ & TIDAK OK \\
& Lumpur Aktif 3 & 12,2 & $1,5-2,5$ & TIDAK OK \\
\hline \hline
\end{tabular}

Hasil evaluasi proses pengolahan biologis menyatakan bahwa dari 5(lima) parameter yang digunakan dalam evaluasi tidak memenuhi kriteria desain, untuk hasil optimasi dapat dilihat pada tabel 3 .

Tabel 3. Optimasi Proses Pengolahan Biologis

\begin{tabular}{|c|c|c|c|c|}
\hline Parameter & Unit & Nilai & $\begin{array}{c}\text { Kriteria } \\
\text { Desain }\end{array}$ & keterangan \\
\hline \multirow[t]{2}{*}{ MLSS (mg/l) } & Lumpur Aktif 1 & 1223 & $1500-4000$ & Tidak OK \\
\hline & Lumpur Aktif 2 & 774 & $1500-4000$ & Tidak OK \\
\hline \multirow{2}{*}{$\begin{array}{l}\mathrm{SF} \\
\left(\mathrm{kg} / \mathrm{m}^{2} . \text { hari }\right)\end{array}$} & Lumpur Aktif 1 & 1,17 & $0,8-1$ & Tidak OK \\
\hline & Lumpur Aktif 2 & 0,6 & $0,8-1$ & Tidak OK \\
\hline \multirow[t]{2}{*}{$\begin{array}{l}\mathrm{F} / \mathrm{M}(\mathrm{kg} \\
\mathrm{BOD} / \mathrm{kg} \\
\mathrm{MLSS})\end{array}$} & Lumpur Aktif 1 & 0,08 & $0,05-0,2$ & OK \\
\hline & Lumpur Aktif 2 & 0,1 & $0,05-0,2$ & OK \\
\hline \multirow[t]{2}{*}{ Td (jam) } & Lumpur Aktif 1 & 2,5 & $1,5-2,5$ & OK \\
\hline & Lumpur Aktif 2 & 2,8 & $1,5-2,5$ & OK \\
\hline \multirow{2}{*}{$\begin{array}{l}\text { Kebutuhan } \\
\text { Udara } \\
\left(\mathrm{m}^{3} / \text { hari) }\right.\end{array}$} & Lumpur Aktif 1 & 121,5 & $190-125$ & OK \\
\hline & Lumpur Aktif 2 & 105 & $190-125$ & $\mathrm{OK}$ \\
\hline
\end{tabular}

\section{F. Perhitungan Estimasi Biaya Pemeliharaan Tiap Bulan}

Untuk mengetahui estimasi biaya pemeliharaan tiap bulan, maka perlu adanya perhitungan biaya. Untuk itu perlu adanya perhitungan pada masing-masing lumpur aktif.

Pada perhitungan evaluasi, debit lumpur yang dibuang ke bak pengendap II, nilai debit yang paling besar yaitu pada bak aerasi 1 , sehingga bak aerasi 1 menjadi acuan untuk menghitung perkiraan voltase pompa.

- Perhitungan pompa

Debit lumpur yang dibuang ke BP II(Qw) $=10,69 \mathrm{~m}^{3} / \mathrm{hari}$

Misalkan pemompaan lumpur dari BP II ke bak aerasi $80 \%$ dari jumlah lumpur

$$
\begin{aligned}
\text { Qrecycle } & =80 \% \times \mathrm{Qw} \\
& =80 \% \times 10,69 \mathrm{~m}^{3} / \text { hari } \\
& =8,5 \mathrm{~m}^{3} / \mathrm{hari} \\
& =0,35 \mathrm{~m}^{3} / \mathrm{jam}
\end{aligned}
$$

Pompa yang dibutuhkan dengan spesifikasi voltase $=0,25$ $\mathrm{kW}$

- Perhitungan blower 1

Kebutuhan udara lumpur aktif $1=5,06 \mathrm{~m} 3 / \mathrm{jam}$

Untuk pemilihan blower ditambah ekstra $5 \%$ untuk kebutuhan udara $=5,31 \mathrm{~m} 3 / \mathrm{jam}$

Didapatkan spesifikasi blower dengan voltase 19,8 W $(0,47 \mathrm{kWh})$, minimal speed 4500 min-1,dan maksimal tekanan statis $185 \mathrm{~Pa}$.

- Perhitungan blower 2
Kebutuhan udara lumpur aktif $2=4,37 \mathrm{~m} 3 / \mathrm{jam}$

Untuk pemilihan blower ditambah ekstra 5\% untuk kebutuhan udara $=4,58 \mathrm{~m} 3 / \mathrm{jam}$

Didapatkan spesifikasi blower dengan voltase $12,0 \mathrm{~W}$ $(0,28 \mathrm{kWh})$, minimal speed 3400 min-1,dan maksimal tekanan statis $185 \mathrm{~Pa}$.

Setelah mendapatkan voltase yang dibutuhkan, perlu adanya penyesuaian harga listrik menurut data harga satuan listrik untuk dijadikan acuan estimasi biaya pemeliharaan tiap bulan seperti pada tabel 4 .

Tabel 4.

Estimasi Biaya Pemeliharaan Proses Pengolahan Lumpur Aktif

\begin{tabular}{ccccccc}
\hline \hline Uraian & jumlah & Satuan & $\begin{array}{c}\text { voltase } \\
(\mathbf{k W h})\end{array}$ & $\begin{array}{c}\text { Harga Satuan } \\
(\mathbf{R p})\end{array}$ & Harga (Rp)/bulan \\
\hline blower & 1 & buah & 0,47 & $\mathrm{Rp} \mathrm{1.353}$ & $\mathrm{Rp}$ & 457.855 \\
blower & 1 & buah & 0,28 & $\mathrm{Rp} \mathrm{1.353}$ & $\mathrm{Rp}$ & 272.765 \\
pompa & 2 & buah & 0,25 & $\mathrm{Rp} \mathrm{1.353}$ & $\mathrm{Rp}$ & 487.080 \\
$\begin{array}{c}\text { upah } \\
\text { teknisi }\end{array}$ & 7 & orang & - & $\mathrm{Rp} \mathrm{1.200.000}$ & $\mathrm{Rp}$ & 8.400 .000 \\
& \multicolumn{7}{c}{ Total Biaya/bulan } & & Rp & $\mathbf{9 . 6 1 7 . 7 0 0}$ \\
\hline \hline
\end{tabular}

\section{KESIMPULAN/RINGKASAN}

Hasil evaluasi dimensi perhitungan dengan dimensi aktual tidak sesuai,dan perbandingan antara perhitungan proses lumpur aktif dengan baku mutu tidak optimal sehingga pengolahan lumpur aktif saat ini tidak sesuai dengan kapasitas dimensi unit dan perhitungan baku mutu. Hasil optimasi pada proses lumpur aktif yaitu nilai MLSS pada bak aerasi 1 sebesar $1223 \mathrm{mg} / \mathrm{l}$ dan bak aerasi 2 sebesar $774 \mathrm{mg} / \mathrm{l}$, solid flux lumpur aktif 1 sebesar $1,17 \mathrm{~kg} / \mathrm{m}^{2}$.hari dan lumpur aktif 2 sebesar 0,6 $\mathrm{kg} / \mathrm{m}^{2}$.hari, F/M rasio lumpur aktif 1 sebesar $0,08 \mathrm{~kg} \mathrm{BOD} / \mathrm{kg}$ MLSS dan lumpur aktif 2 sebesar $0,1 \mathrm{~kg}$ BOD/kg MLSS, waktu detensi lumpur aktif 1 sebesar 2,5 jam dan lumpur aktif 2 sebesar 2,8 jam, kebutuhan udara lumpur aktif 1 sebesar $121,5 \mathrm{~m}^{3} /$ hari, dan lumpur aktif 2 sebesar $105 \mathrm{~m}^{3} /$ hari. Hasil estimasi biaya pemeliharaan menghabiskan dana sebesar Rp. 9.617.700,- per bulan.

\section{UCAPAN TERIMA KASIH}

Penulis mengucapkan terima kasih kepada Industri Penyamakan Kulit Magetan yang telah berkenan untuk dijadikan studi kasus pada evaluasi dan optimasi IPAL Industri Penyamakan Kulit.

\section{DAFTAR PUSTAKA}

[1] Nurwati. 2009. Pengaruh Limbah Cair Industri Penyamakan Kulit terhadap Kadar Kromium dalam Tanaman Jahe (Zinggiber officanale). UIN Sunan Kalijaga. Yogyakarta.

[2] Junaidi, Zainus dan Maria. 2013. Pengelolaan Logam Berat Khrom (Cr) pada Limbah Cair Industri Penyamakan Kulit dengan Proses Koagulasi Flokulasi dan Presipitasi. Universitas Diponegoro Vol 2 No 2. 
[3] Setiyono dan Yudo, S., 2014. Daur Ulang Air Limbah Industri Penyamakan Kulit. Badan Pengkajian dan Penerapan Teknologi ISBN: 978-602-1124-16-1. Jakarta Pusat

[4] Cahyono. 2012. Bangunan Pengolahan Air Buangan Industri Penyamakan Kulit. UPN Veteran. Surabaya.

[5] Peraturan Gubernur Jawa Timur Nomor 72 Tahun 2013 Tentang Baku Mutu Bagi Industri dan/atau Kegiatan Usaha Lainnya.

[6] Widjaja T. 2012. Pengolahan Limbah Industri (Proses Biologis). Surabaya : Teknik Kimia ITS.

[7] Metcalf dan Eddy. 2003. Wastewater Engineering: Treatment and Reuse, $4^{\text {rd }}$ ed. New York: McGraw-Hill.

[8] Eckenfelder, W. W. dan Grau. P. 1998. Activated Sludge Process Design and Control Theory and Practice. USA : Technomic Publishing CO INC.

[9] Metcalf dan Eddy. 1991. Wastewater Engineering: Treatment and Reuse, $3^{\text {rd }}$ ed. New York: McGraw-Hill. 